Division of Geological \& Geophysical Surveys

PRELIMINARY INTERPRETIVE REPORT 2013-4

\title{
STATUS OF A RECONNAISSANCE FIELD STUDY OF THE SUSITNA BASIN, 2011
}

by

Robert J. Gillis, Richard G. Stanley, David L. LePain, David J. Mauel, Trystan M. Herriott, Kenneth P. Helmold, C. Shaun Peterson, Marwan A. Wartes, and Diane P. Shellenbaum

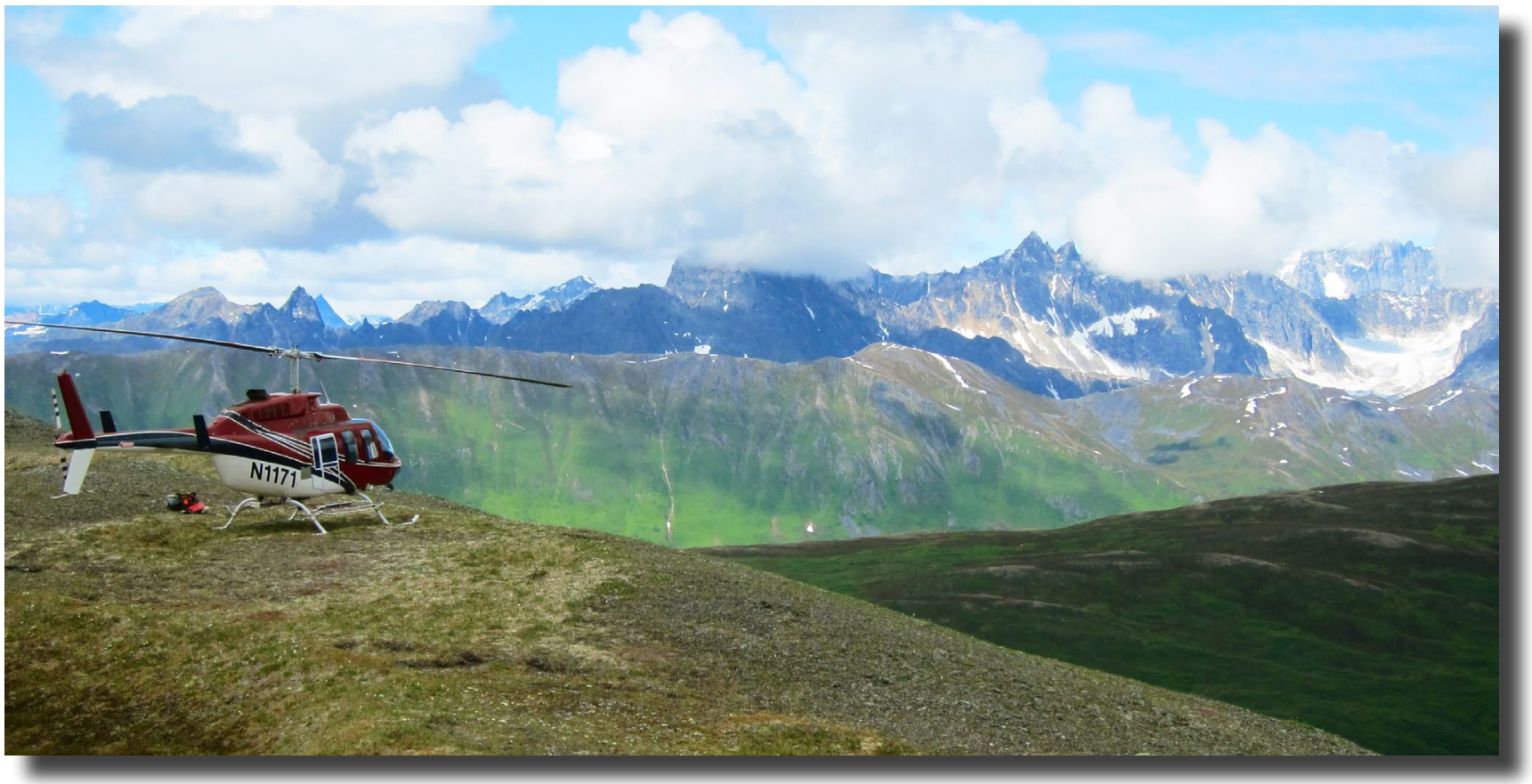

View from the Dutch Hills at the northwest margin of the Susitna basin, looking northwestward toward the western Alaska Range. Cretaceous-age marine metasedimentary successions of the Kahiltna group (fore and middle ground), and exhumed intrusive rocks such as the Kahiltna pluton composing the skyline, were likely principal sediment sources to the Susitna basin during Cenozoic time.

\author{
April 2013 \\ Released by \\ STATE OF ALASKA \\ DEPARTMENT OF NATURAL RESOURCES \\ Division of Geological \& Geophysical Surveys \\ 3354 College Rd.. Fairbanks, Alaska 99709-3707
}





\section{CONTENTS}

Introduction... 1

Geologic setting . .1

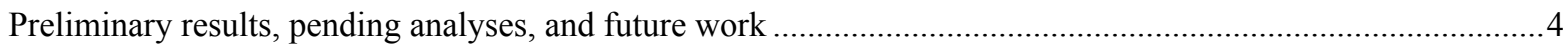

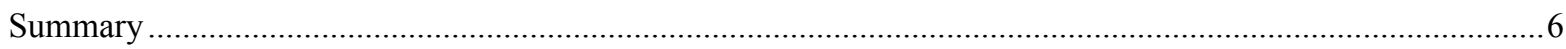

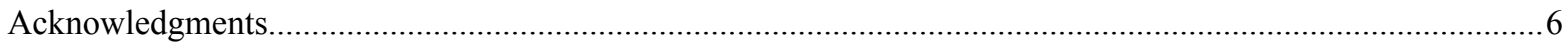

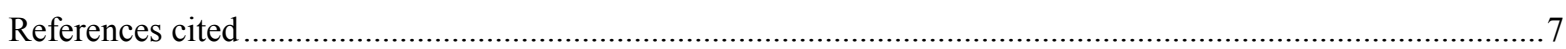

\section{FIGURES}

Figure 1. Generalized geologic map showing Susitna basin relative to upper Cook Inlet basin, western Alaska Range, Talkeetna Mountains, and major known and inferred geologic structures 2

2. Generalized stratigraphic columns for the Cook Inlet forearc basin and exhumed correlative strata along strike to the northeast in the Matanuska Valley..... 3

3. Sedimentary rocks in outcrop along Contact Creek about $100 \mathrm{~km}$ southwest of Talkeetna................5

4. Geologist Dave LePain collecting a sandstone sample to be to be analyzed for its oil and gas reservoir potential.

5. Geologist Dave LePain examining an outcrop of conglomerate along Lake Creek about $50 \mathrm{~km}$ southwest of Talkeetna. 



\title{
STATUS OF A RECONNAISSANCE FIELD STUDY OF THE SUSITNA BASIN, 2011
}

\author{
by \\ Robert J. Gillis ${ }^{1}$, Richard G. Stanley ${ }^{2}$, David L. LePain ${ }^{1}$, David J. Mauel ${ }^{1}$, Trystan M. Herriott ${ }^{1}$, \\ Kenneth P. Helmold ${ }^{3}$, C. Shaun Peterson ${ }^{3}$, Marwan A. Wartes ${ }^{1}$, and Diane P. Shellenbaum ${ }^{3}$
}

\section{INTRODUCTION}

The Alaska Division of Geological \& Geophysical Surveys (DGGS) and Alaska Division of Oil and Gas (DOG), in collaboration with the U.S. Geological Survey (USGS) performed reconnaissance field studies for ten days in late June 2011, in the Susitna basin, directly north of Cook Inlet, south-central Alaska (fig. 1). The purpose of our investigation was to reconnoiter outcrops in the basin and along its periphery to gather new information towards understanding the basin formation history and stratigraphy. This reconnaissance data represents the first step toward better understanding the basin's hydrocarbon potential, a key component of DGGS's multi-year InState Gas Program. This program is focused on collecting baseline geologic information from potential frontier gas basins to encourage new exploration to help, in part, reduce the high cost of energy in rural Alaska. Our work represents the first season of this three-year project. Preliminary results from year two, a companion project within the Nenana and Tanana basins in interior Alaska, are described by Wartes and others (2013). DGGS plans to return to the Susitna basin for follow-up fieldwork during the third and final year of the program.

The motivation for developing a better understanding of the Susitna basin stems from the recognition that the Susitna basin shares similar age coal-bearing strata with the adjacent, petroliferous Cook Inlet forearc basin (Barnes, 1966; Reed and Nelson, 1980) and with exhumed strata in the Matanuska Valley forearc basin (Trop and others, 2003) (figs. 1 and 2). Cook Inlet basin has eight producing oil fields, more than 25 producing gas fields, and likely contains many additional undiscovered oil and gas accumulations (LePain and others, in press). Most of the Cook Inlet gas is of microbial origin and apparently was sourced from abundant coalbeds of primarily Miocene age in the Tyonek, Beluga, and Sterling Formations (Claypool and others, 1980; Magoon, 1994). If the biogenic gas model for Cook Inlet is applicable to the Susitna basin, then the latter may be a viable source for Alaska Railbelt and rural energy needs.

This brief overview report summarizes the reconnaissance field data collected in the Susitna basin during the first summer of the program. As the data are developed, this report will be followed by interpretive technical reports addressing the stratigraphy, reservoir quality, coal quality and gas potential, hydrocarbon seal integrity, subsurface structure, and uplift history of the basin and sub-basin margins.

\section{GEOLOGIC SETTING}

The Susitna basin is a broad lowland $(\sim 13,000 \mathrm{~km} 2)$ bordered by the Alaska Range on the west and north and the Talkeetna Mountains on the east. On the south, the Susitna basin is separated from the Beluga and Cook Inlet basins by the Castle Mountain fault (fig. 1). The Susitna basin can be subdivided into two sub-basins, the Susitna and Yentna depocenters, which occur on either side of a southwest-trending basement high that crops out in the Yenlo Hills and consists of Cretaceous metasedimentary rocks (fig. 1). The Susitna depocenter is southeast of the basement high, deepens toward the southwest, and contains at least 3-4 km of siliciclastic sedimentary fill (Hackett, 1977; Ehm, 1983; Kirschner, 1988; Meyer, 2005). The Yentna depocenter (Hackett, 1977), also known as the Peters Hills basin (Haeussler, 2008; Haeussler and others, 2008), is northwest of the basement high and is smaller and probably not as thick as the Susitna depocenter (Meyer, 2005).

The general lack of bedrock exposures and subsurface data has resulted in poor understanding of the stratigraphy and structure of the Susitna basin. Few exposures of Cenozoic sedimentary rocks exist in the Susitna lowlands, and basin-controlling structures are often covered or poorly expressed. The oldest Cenozoic strata mapped at the surface are of Miocene age (Barnes, 1966; Reed and Nelson, 1980). Only 12 exploratory wells have been drilled in the Susitna basin, and half of these are concentrated in a small area near Houston on the extreme southeastern margin of the basin.

${ }^{1}$ Alaska Division of Geological \& Geophysical Surveys, 3354 College Road, Fairbanks, AK99709-3707

${ }^{2}$ U.S. Geological Survey, 345 Middlefield Road Mail Stop 969, Menlo Park CA 94025-3561

${ }^{3}$ Alaska Division of Oil \& Gas, 550 W. $7^{\text {th }}$ Avenue, Anchorage, AK 99501 


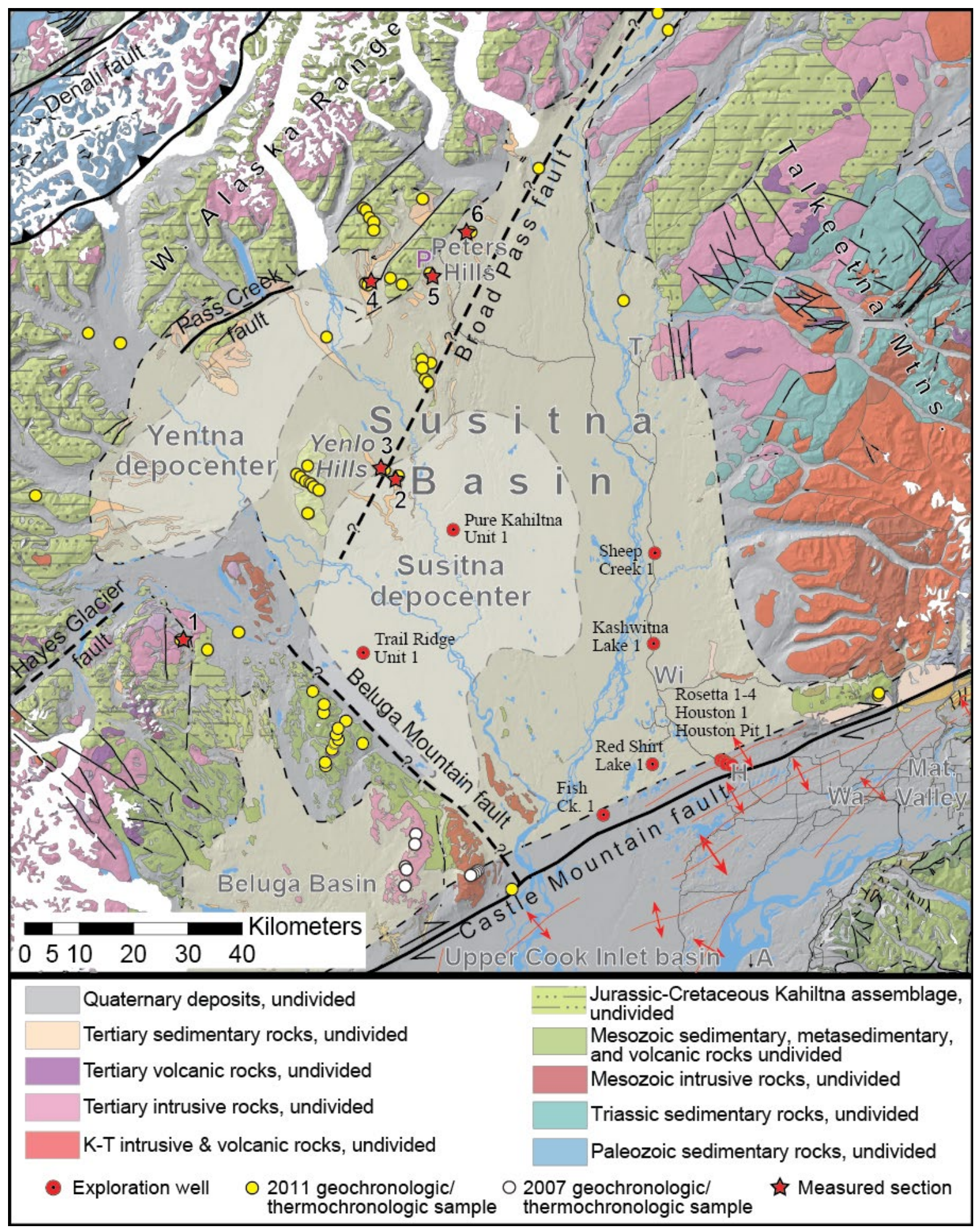

Figure 1. Generalized geologic map (adapted from Wilson and others, 2009) showing Susitna basin relative to upper Cook Inlet basin, western Alaska Range, Talkeetna Mountains, and major known and inferred geologic structures. The greater Susitna basin is shaded tan (Meyer, 2005), whereas the Susitna and Yentna depocenters are shaded off-white (adapted from Meyer, 2005). Red stars with black numbers represent measured stratigraphic sections mentioned in text $(1=$ Contact Creek, $2=$ Lake Creek, $3=$ Lake Creek, $4=$ Spruce Creek, $5=$ Big Creek, 6 = Bunco Creek); red circles with black dots represent exploration wells; and yellow and white dots represent locations of geochronologic and thermochronologic samples collected in 2011 and 2007. Also shown are Beluga basin and Beluga Mountain fault (Hackett, 1977), Hayes Glacier fault (Solie and Layer, 1993), Pass Creekfault (Capps, 1913; Barnes, 1966; Reed and Nelson, 1980), and Broad Pass fault (Haeussler, 2008; Haeussler and others, 2008). Mat. Valley = Matanuska Valley, $A=$ Anchorage, Wa = Wasilla, $H=$ Houston, Wi $=$ Willow, $T=$ Talkeetna, $P=$ Petersville. 
The sparse available geologic exposures and data mean that little is known about the geologic history of the Susitna basin and its relationship to the much larger and better studied Cook Inlet basin. For example, the timing and cause of initial subsidence in the Susitna basin are uncertain because the age of the oldest basin fill is unknown. Trop and Ridgway (2007) suggested that the oldest strata in the Susitna basin may be Paleocene in age, whereas Meyer and Boggess (2003) implied that the oldest basin fill may be of Oligocene age or younger. The lack of geologic information makes it difficult to evaluate the assertions of previous authors (Merritt, 1986; Rouse and Houseknecht, 2012) that the Susitna basin is a northern continuation of the Cook Inlet basin.

We note that the region of subsidence defining the Susitna basin partially cuts across the early Cenozoic magmatic arc (fig. 1). Therefore, if the Cook Inlet and Susitna basins are contemporaneous (Paleocene and younger), then the Susitna basin did not initiate in a forearc position and required a different mechanism for subsidence early in its history. An additional complication is that the Susitna and Cook Inlet basins are on opposing blocks of the Castle Mountain fault, which is an active, regional-scale, right-lateral strike-slip and up-to-the-north fault (Grantz, 1966; fig. 1). The slip history of the Castle Mountain fault is incompletely understood but may have been underway by Late Cretaceous or Paleocene time (Grantz, 1966; Trop and others 2003), prior to the development of the Cook Inlet and Susitna basins. Thus, a genetic relationship between the Susitna and Cook basins has not been determined.

Figure 2. Generalized stratigraphic columns for the Cook Inlet forearc basin and exhumed correlative strata along strike to the northeast in the Matanuska Valley (adapted from Trop and others, 2003). Cenozoic strata in the Susitna basin are thought to be genetically related to coal-bearing rocks in the forearc basin to the south and southeast (Merritt, 1986) despite their separation by the Castle Mountain fault (fig. 1), a major structural element since latest Cretaceous and Paleocene time (Grantz, 1966; Trop and others, 2003).

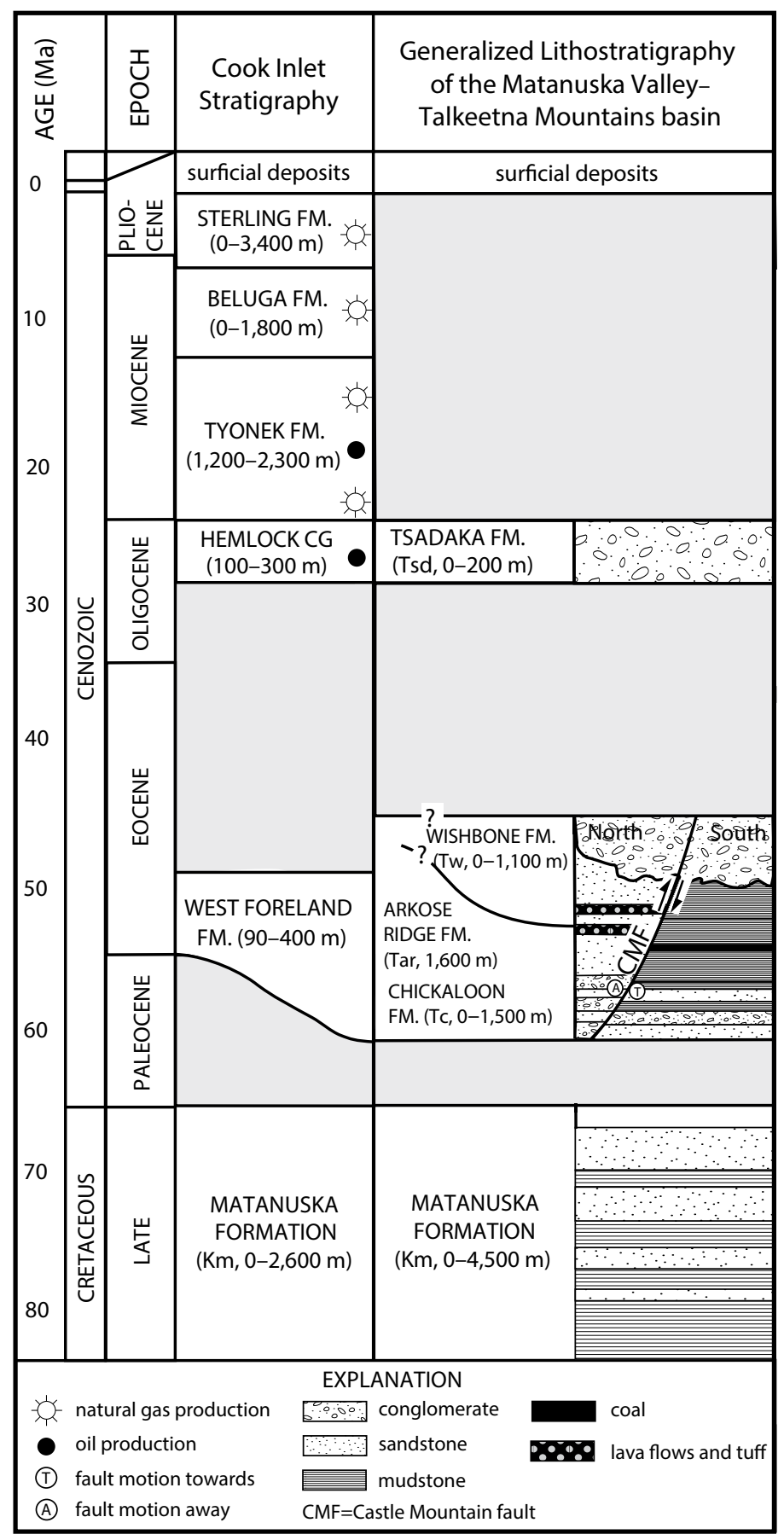




\section{PRELIMINARY RESULTS, PENDING ANALYSES, AND FUTURE WORK}

Reconnaissance fieldwork led by DGGS in 2011 focused on resolving the uncertainties related to the timing and mode of Susitna basin development, as well as developing a better understanding of the stratigraphic architecture and depositional setting of the basin fill where exposed at the surface. The rare exposures of Cenozoic strata in the Susitna basin are found around the basin periphery and along creek incisions. Our initial stratigraphic studies in 2011 (red stars in fig. 1) focused on Cenozoic outcrops along Contact Creek (fig. 3), Lake Creek (figs. 4 and 5), Spruce Creek, Big Creek, and Bunco Creek. Outcrops at these localities were mainly composed of fluvial trough cross-stratified sandstone, siltstone, and conglomerate. Reservoir quality and hydrocarbon seal capacity samples were collected from measured sections at each location to determine the reservoir potential of the strata. Thirtytwo palynological and 12 detrital zircon (DZ) analyses from six measured stratigraphic sections at these sites will help to constrain depositional ages and provide new insights into sediment provenance.

Based on interpretations of regional gravity data by Hackett (1977) and Meyer (2005), and preliminary examination of proprietary seismic data during this study, the Susitna depocenter thickens southwestward toward an inferred fault (the Beluga Mountain fault of Hackett, 1977; fig. 1). Displacement along this inferred fault may partly control sediment accommodation in the basin, and has been interpreted variously as either a southwestdipping reverse fault (Saltus, and others, 2012; Hackett, 1977) or a northeast-dipping normal fault (Kirschner, 1988). Therefore, determining its existence and structural style is critical to developing a model for subsidence of the Susitna basin. A reconnaissance traverse up a deeply incised drainage that crosses the northeast topographic front of Beluga Mountain through Quaternary cover and into volcaniclastic and metavolcanic rocks believed to be Cretaceous in age did not reveal a fault contact. Additional attempts to locate probable basin-bounding faults in this area will be undertaken during the final year of the In-State Gas Program.

Forty-five apatite fission-track (AFT) and (U-Th)/He (AHe) samples from surrounding Mesozoic and Cenozoic bedrock exposures (fig. 1) are currently being analyzed to ascertain their low-temperature cooling histories. These data will help constrain when and how quickly basin margin sediment sources were eroded and exhumed. Analyses of eight detrital AFT samples from Cenozoic basin fill tied to measured stratigraphic sections, nine DZ samples from Mesozoic source terranes, and six DZ and detrital AFT samples from modern river sands will help link sediment source areas to sinks (fig. 1).

Future field studies in the Susitna basin during year three of the In-State Gas Program will continue to focus on examining discontinuous exposures of Cenozoic stratigraphy and structures mapped along the western periphery of the basin by Barnes (1966) and Reed and Nelson (1980). The goal will be to better understand the rapid lateral changes in sedimentary facies parallel to the basin margin (deduced from Reed and Nelson, 1980), and the structural controls on basin subsidence. This knowledge will enable us to better predict the distribution of reservoir and seal lithologies in the subsurface, as well as the potential for structural and stratigraphic gas traps. Additionally, DGGS has permission to publish two proprietary seismic lines oriented orthogonally to each other that image the deepest region of the basin. Our field geologic and stratigraphic data will be combined with interpretations regarding structural controls on basin subsidence from these seismic lines and proprietary well information to ultimately develop a stratigraphic and structural model for the Susitna basin to better assess its potential as a conventional gas province, though we recognize the challenges of working from such a sparse and widely scattered set of outcrop and subsurface data. We will collect a suite of coal samples for laboratory analyses to determine their potential as primary fuel sources, and coal cleat data to better understand the capacity of the coalbeds to produce and store methane gas. 


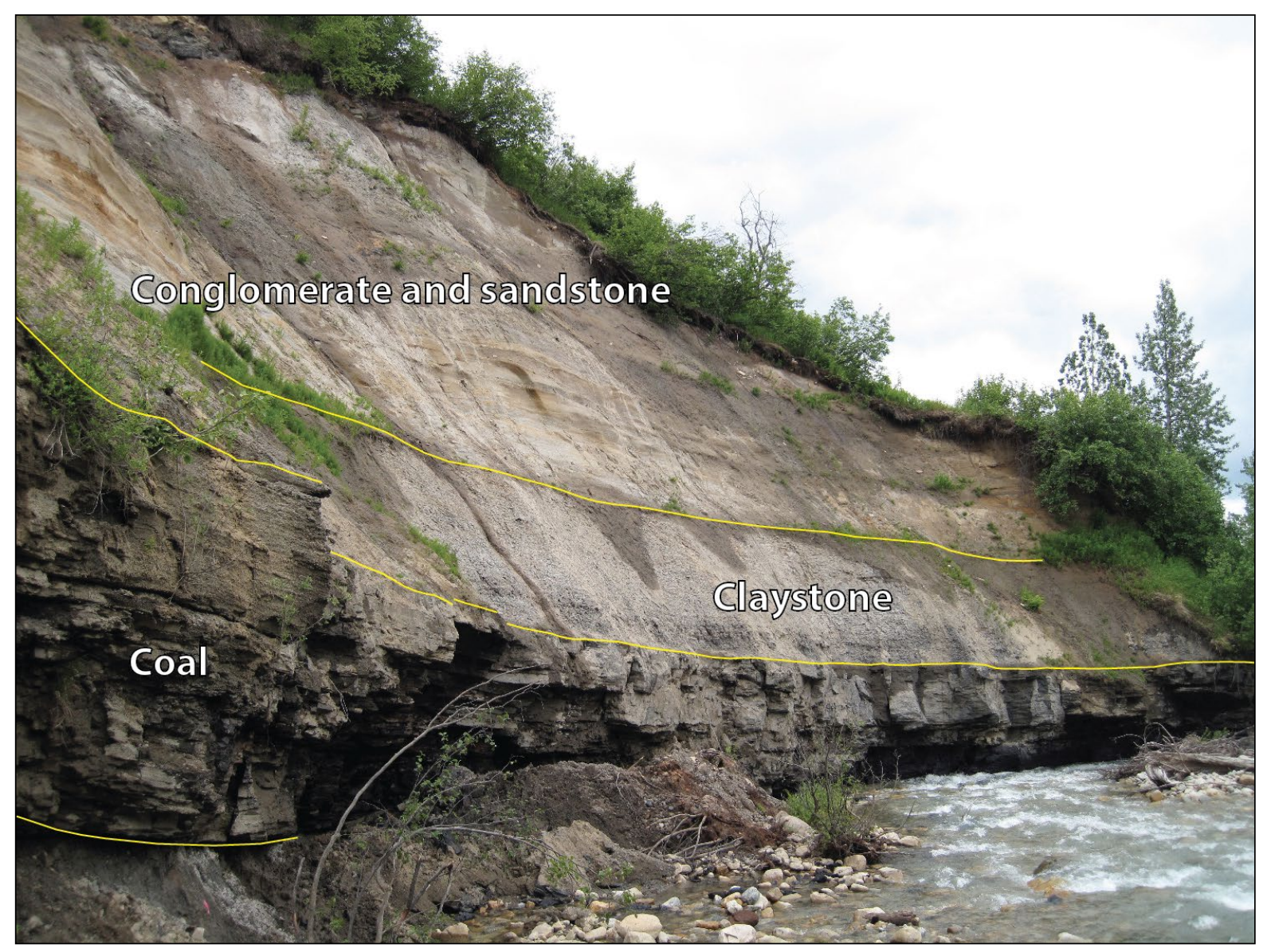

Figure 3. Sedimentary rocks in this outcrop along Contact Creek about $100 \mathrm{~km}$ southwest of Talkeetna (fig. 1, location 1) were deposited by ancient rivers and may be similar to strata that are deeply buried nearby in the Susitna sedimentary basin. Analysis of fossil pollen in rock samples from this outcrop show that the strata are of Oligocene or Miocene age. A dark-colored 4-m-thick layer of coal forms a prominent vertical cliff adjacent to the creek. Above the coal is a gray-colored layer of claystone about $3 \mathrm{~m}$ thick, which in turn is overlain by an orange- and tan-colored sequence of conglomerate and sandstone about $12 \mathrm{~m}$ thick. Similar horizons of sandstone and conglomerate may serve as reservoir rocks for natural gas derived from coal source rocks in the Susitna basin. Photo by Rick Stanley (USGS), 2011. 


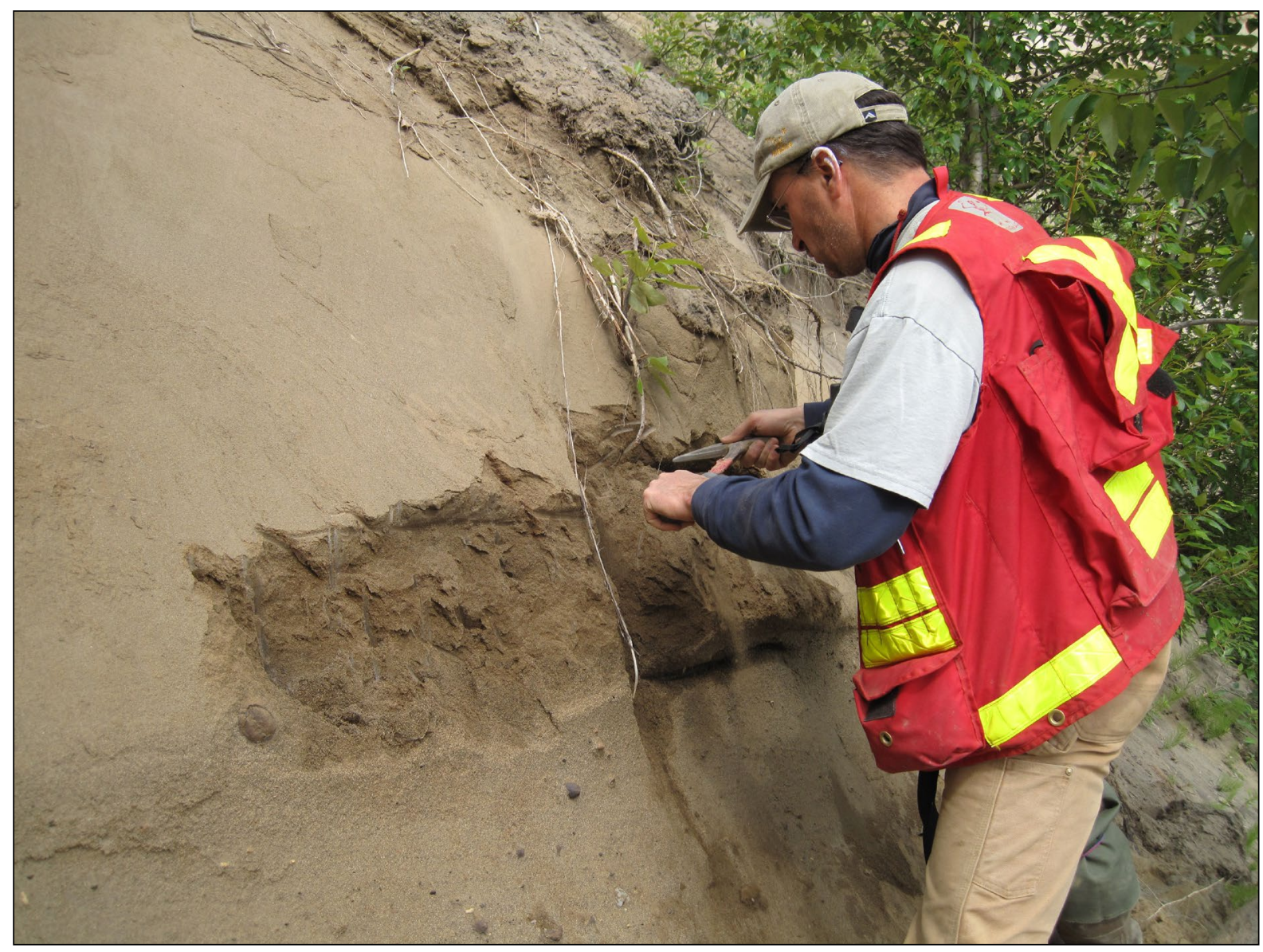

Figure 4. Geologist Dave LePain (DGGS) collecting a sandstone sample to be to be analyzed for its oil and gas reservoir potential. This outcrop is about $48 \mathrm{~km}$ southwest of Talkeetna along Lake Creek (fig. 1, location 3). The sandstone was deposited by an ancient river, and analysis of fossil pollen from this locality indicates these strata are of Oligocene or Miocene age. Similar beds of sandstone at depth in the Susitna basin may serve as reservoir rocks for natural gas. Photo by Rick Stanley (USGS), 2011.

\section{SUMMARY}

The collaborative reconnaissance field studies in the Susitna basin by DGGS, DOG, and USGS described in this report provide new outcrop-based stratigraphic data of Cenozoic basin-fill deposits within and along the margin of the Susitna basin. Analyses of bedrock and basin-fill samples are in progress and expected to provide information useful for assessing reservoir and hydrocarbon seal quality, sediment provenance, and source terrane cooling histories. Our new data will be combined with existing seismic data and used to better understand the basin formation history and stratigraphy of the Susitna basin. These data will be made available to the public in a series of subsequent interpretive reports and raw data files focused on disseminating new geologic data related to the basin's hydrocarbon potential.

\section{ACKNOWLEDGMENTS}

We would like to thank Peter Haeussler and Jeff Trop for showing us around the Susitna basin at the beginning of the 2011 field season; Pathfinder Aviation and pilots Merlin (Spanky) Handley and Chuck Redd for safely and skillfully flying our crews into and out of remote field locations; the proprietors and staff at Sheep Creek Lodge for their hospitality; Keane Richards for field and office support; and Paul Decker, Rich Koehler, and Peter Haeussler for constructive reviews. This project was funded by the State of Alaska. 


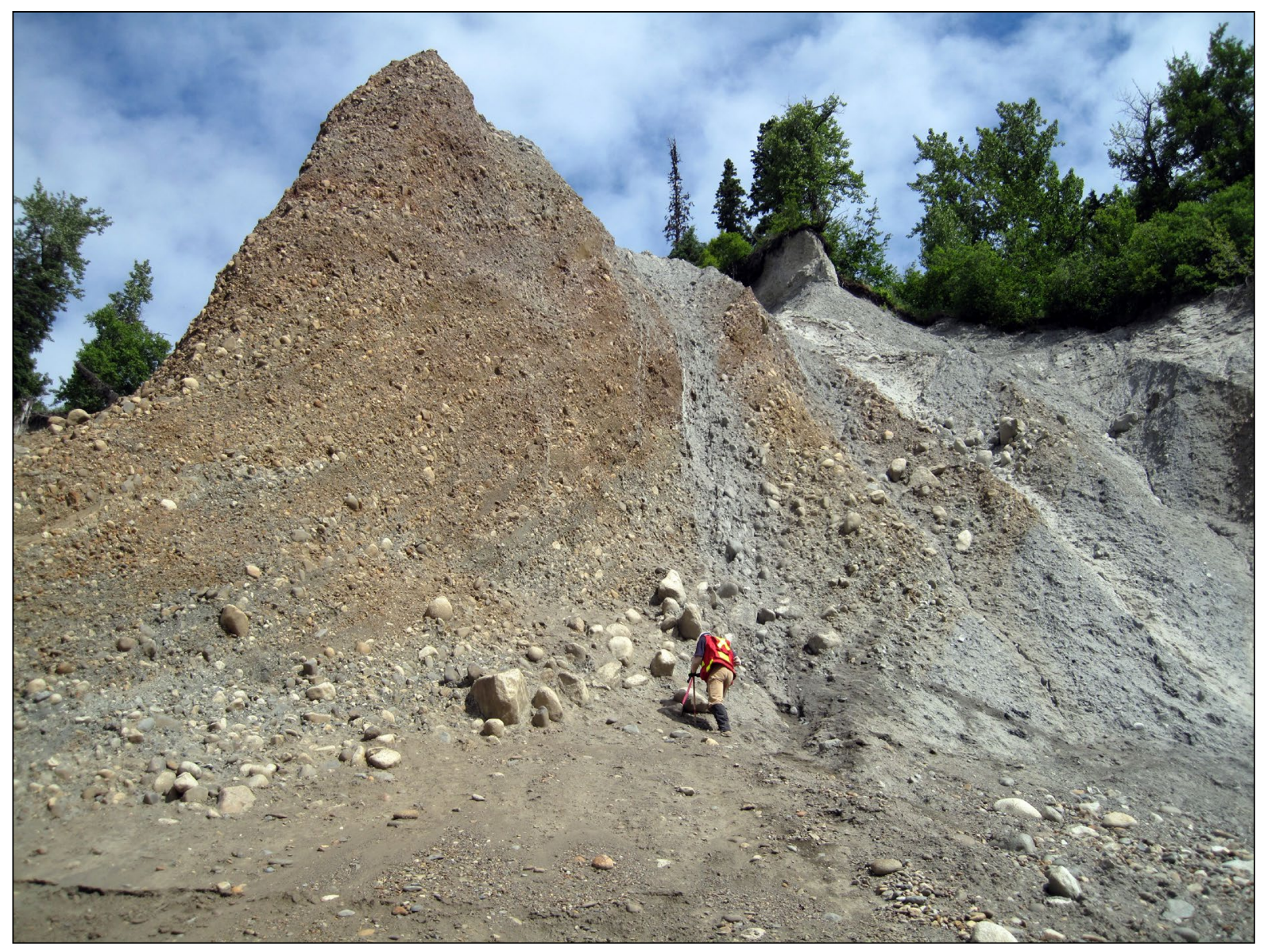

Figure 5. Geologist Dave LePain (DGGS) examining an outcrop of conglomerate along Lake Creek about $50 \mathrm{~km}$ southwest of Talkeetna (fig. 1, location 2). Analysis of fossil pollen from this outcrop suggests that the conglomerate is of Oligocene or younger age. Pebbles, cobbles, and boulders up to $1 \mathrm{~m}$ in diameter in the conglomerate are consistent with deposition on an ancient alluvial fan and include abundant clasts of granitic and volcanic rocks as well as black argillite. The uncommonly large clast sizes and locally pervasively fractured subvertical beds at this location may suggest deposition near a contemporaneously growing structure. Similar conglomeratic horizons and age-equivalent sandstones nearby in the Susitna basin subsurface may be reservoirs for accumulations of natural gas. Photo by Rick Stanley (USGS), 2011.

\section{REFERENCES CITED}

Barnes, F.F., 1966, Geology and coal resources of the Beluga-Yentna region, Alaska: U.S. Geological Survey Bulletin 1202-C, 67 p., 7 sheets, scale 1:63,360.

Capps, S.R., 1913, The Yentna district, Alaska: U.S. Geological Survey Bulletin 534, 75 p., 2 sheets, scale 1:250,000. Canadian Stratigraphic Services Lithologic Logs, www.canstrat.com (choose log index for details).

Claypool, G.E., Threlkeld, C.N., and Magoon, L.B., 1980, Biogenic and thermogenic origins of natural gas in Cook Inlet basin, Alaska: American Association of Petroleum Geologists Bulletin, v. 64, p. 1,131-1,139.

Grantz, Arthur, 1966, Strike-slip faults in Alaska: U.S. Geological Survey Open-File Report 66-53, 82 p.

Ehm, Arlen, 1983, Oil and gas basins map of Alaska: Alaska Division of Geological \& Geophysical Surveys Special Report 32, 1 sheet, scale 1:2,500,000.

Hackett, S.W., 1977, Gravity survey of Beluga Basin and adjacent area, Cook Inlet region, south-central Alaska: Alaska Division of Geological \& Geophysical Surveys Geologic Report 49, 31 p., 3 sheets, scale 1:528,000.

Haeussler, P.J., 2008, An overview of the neotectonics of interior Alaska-Far-field deformation from the Yakutat microplate collision, in Freymueller, J.T., Haeussler, P.J., Wesson, R.L., and Ekstrom, G., eds., Active Tectonics and Seismic Potential of Alaska: American Geophysical Union Geophysical Monograph 179, p. 269-285. 
Haeussler, P.J., Saltus, R.W., Ruppert, N., and Karl, S.M., 2008, Evidence for Pliocene to present thrust faulting on the south side of the Alaska Range in the vicinity of the Peters Hills piggyback basin: Eos Transactions, AGU, v. 89, no. 53, Fall Meeting Supplement Abstract T44A-08.

Kirschner, C.E., 1988, Map showing sedimentary basins of onshore and continental shelf areas, Alaska: U.S. Geological Survey Miscellaneous Investigations Series Map 1873, 1 sheet, scale 1:2,500,000.

LePain, D.L., Stanley, R.G., and Helmold, K.P., in press, Geologic framework of Cook Inlet basin, south-central Alaska, in Stone, D.M., and Hite, D.M., eds., Oil and gas fields of the Cook Inlet basin: American Association of Petroleum Geologists.

Magoon, L.B., 1994, Petroleum resources in Alaska, in Plafker, George, and Berg, H.C., eds., The geology of Alaska: Boulder, Colorado, Geological Society of America, The Geology of North America, v. G-1, p. 905-936.

Merritt, R.D., 1986, Coal geology and resources of the Susitna Lowland, Alaska: Alaska Division of Geological \& Geophysical Surveys Public Data File 86-75, 98 p.

Meyer, J.F., 2005, Principal facts for gravity data collected in the northern Susitna Basin area, south-central Alaska: Alaska Division of Geological \& Geophysical Surveys Preliminary Interpretive Report 2005-5, 12 p.

Meyer, J.F., and Boggess, P.L., 2003, Principal facts for gravity data collected in the Susitna area, south-central Alaska: Alaska Division of Geological \& Geophysical Surveys Preliminary Interpretive Report 2003-3, 13 p.

Reed, B.L., and Nelson, S.W., 1980, Geologic map of the Talkeetna Quadrangle, Alaska: U.S. Geological Survey Miscellaneous Investigations Series Map 1174, 15 p., 1 sheet, scale 1:250,000.

Rouse, W.A., and Houseknecht, D.W., 2012, Assessment of the Coal-Bed Gas Total Petroleum System in the Cook Inlet-Susitna region, south-central Alaska: U.S. Geological Survey Scientific Investigations Report 2012-5145, 19 p., available at http://pubs.usgs.gov/sir/2012/5145/.

Solie, D.N., and Layer, P.W., 1993, The Hayes Glacier fault, southern Alaska Range: Evidence for post Paleocene movement, in Solie, D.N., and Tannian, Fran, Short Notes on Alaskan Geology 1993: Alaska Division of Geological \& Geophysical Surveys Professional Report 113H, p. 71-80.

Saltus, R.W., Haeussler, P.J., Jones, J.V., III, Lewis, K.A., and Stanley, R.G., 2012, Gravity and magnetic investigation of Susitna basin structure, Cook Inlet, Alaska: Geological Society of America Annual Meeting November 4-7, 2012, Charlotte, NC, Abstracts and Programs.

Swenson, R.F., 2001, Introduction to Tertiary tectonics and sedimentation in the Cook Inlet basin, in Dallegge, T.A., comp., 2003, 2001 Guide to the Petroleum Geology and Shallow Gas Potential of the Kenai Peninsula, Alaska-A Field Trip Guidebook: Alaska Division of Geological \& Geophysical Surveys Miscellaneous Publication 128, 89 p., 1 disk.

Trop, J.M., and Ridgway, K.D., 2007, Mesozoic and Cenozoic tectonic growth of southern Alaska-A sedimentary basin perspective, in Ridgway, K.D., Trop, J.M., Glen, J.M.G., and O’Neill, J.M., eds., Tectonic Growth of a Collisional Continental Margin - Crustal Evolution of Southern Alaska: Geological Society of America Special Paper 431, p. 55-94.

Trop, J.M., Ridgway, K.D., and Spell, T.L., 2003, Sedimentary record of transpressional tectonics and ridge subduction in the Tertiary Matanuska Valley-Talkeetna Mountains forearc basin, southern Alaska: Geological Society of America Special Paper 371, p. 89-118.

Wartes, M.A., Gillis, R.J., Herriott, T.M., Stanley, R.G., Helmold, K.P., Peterson, C.S., and Benowitz, J.A., 2013, Summary of 2012 reconnaissance field studies related to the petroleum geology of the Nenana Basin, interior Alaska: Alaska Division of Geological \& Geophysical Surveys Preliminary Interpretive Report 2013-2, 13 p.

Wilson, F.H., Hults, C.P., Schmoll, H.R., Haeussler, P.J., Schmidt, J.M., Yehle, L.A., and Labay, K.A., comps., 2009, Preliminary Geologic Map of the Cook Inlet Region, Alaska - Including parts of the Talkeetna, Talkeetna Mountains, Tyonek, Anchorage, Lake Clark, Kenai, Seward, Iliamna, Seldovia, Mount Katmai, and Afognak 1:250,000-scale Quadrangles: U.S. Geological Survey Open-File Report 2009-1108, 52 p., 2 sheets, scale 1:250,000 (available at http://pubs.usgs.gov/of/2009/1108/). 